\title{
Immediate Irrigation Improves Turfgrass Safety to Postemergence Herbicides
}

\author{
Robert Andrew Kerr ${ }^{1}$, Lambert B. McCarty, and Philip J. Brown \\ Department of Plant, and Environmental Sciences, Clemson University, 130 \\ McGinty Court, Clemson, SC 29634
}

James Harris and J. Scott McElroy Department of Crop, Soil, and Environmental Sciences, Auburn University, 233B Funchess Hall, Auburn, AL 36849

Additional index words. Cynodon dactylon Pers. $\times$ Cynodon transvaalensis Burtt-Davy, cv. Tifway 419, turfgrass, weed control

\begin{abstract}
Summer annual grassy weeds such as goosegrass (Eleusine indica L. Gaertn.) continue to be problematic to control selectively with postemergence (POST) herbicides within turfgrass stands. In recent years, reduced performance by certain herbicides (e.g., foramsulfuron), cancellation of goosegrass-specific herbicides (e.g., diclofop-methyl), and cancellation and/or severe use reductions of other herbicides [e.g., monosodium methanearsonate (MSMA)] have limited the options for satisfactory control and maintenance of an acceptable $(\mathbf{3 0 \%}$ visual turfgrass injury) turfgrass quality. Currently available herbicides (e.g., topramezone and metribuzin) with goosegrass activity typically injure warm-season turfgrass species. The objectives of this research were to evaluate both 'Tifway 419' bermudagrass [Cynodon dactylon (L.) Pers. $\times$ Cynodon transvaalensis Burtt-Davy] injury after treatment with POST herbicides, and to determine whether irrigating immediately after application reduces turfgrass injury. Treatments were control ( \pm irrigation); topramezone (Pylex 2.8C; \pm

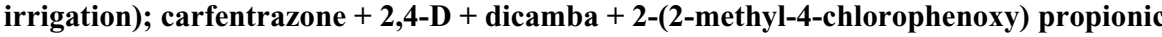
acid (MCPP) (Speedzone 2.2L; \pm irrigation); carfentrazone + 2,4-D + dicamba + MCPP in combination with topramezone ( \pm irrigation); metribuzin (Sencor 75DF; \pm irrigation); mesotrione (Tenacity 4L; \pm irrigation); simazine 4L (tirrigation); and mesotrione + simazine ( \pm irrigation). Irrigated treatments were applied immediately with a hand hose precalibrated to apply $0.6 \mathrm{~cm}$ or 0.25 inch $(\approx 6.3 \mathrm{~L})$. Visual turfgrass injury for combined herbicide treatments for the irrigated plots was $6 \% 4$ days after treatment (DAT), $12 \% 1$ week after treatment (WAT), 17\% 2 WAT, and 6\% 4 WAT, whereas nonirrigated plots had turfgrass injury of $14 \%$ at 4 DAT, 31\% 1 WAT, 35\% 2 WAT, and $12 \% 4$ WAT. Irrigated pots had normalized differences vegetative indices (NDVI) ratings of 0.769 at 4 DAT, 0.644 at 1 WAT, 0.612 at 2 WAT, and 0.621 at 4 WAT, whereas nonirrigated plots had the lowest (least green) turfgrass NDVI ratings of 0.734 at $4 \mathrm{DAT}, 0.599$ at $1 \mathrm{WAT}$, 0.528 at 2 WAT, and 0.596 at 4 WAT. These experiments suggest turfgrass injury could be alleviated by immediately incorporating herbicides through irrigation.
\end{abstract}

Goosegrass (Eleusine indica L. Gaertn.), a weedy $\mathrm{C}_{4}$ grass species throughout much of the world, is problematic to control selectively with POST herbicides within 'Tifway 419' bermudagrass [Cynodon dactylon (L.) Pers. $\times$ Cynodon transvaalensis Burtt-Davy] stands (Lee and Ngim, 2000; McCullough et al., 2016; Mudge et al., 1984). Classified botanically as a summer annual, goosegrass plants are eradicated by the first killing frost. However, in tropical regions, goosegrass behaves like a perennial, continuing to tiller year-round as a result of the lack of frost. Also in tropical regions, year-round seed germination leads to plants with varying

Received for publication 14 Sept. 2018. Accepted for publication 1 Dec. 2018.

${ }^{1}$ Corresponding author. E-mail: rakerr@g.clemson. edu. maturity, resulting in inconsistent preemergence (PRE) and POST control efficacy.

In recent years, reduced performance by certain herbicides (e.g., foramsulfuron), cancellation of goosegrass-specific herbicides (e.g., diclofop-methyl), and cancellation and/or severe use reductions of other herbicides (e.g., MSMA) have limited the options end users have for satisfactory control and maintenance of acceptable turfgrass quality. Currently available herbicides (e.g., topramezone, metribuzin) with activity on goosegrass also often result in unacceptable injury (bleaching) to the desirable turfgrass species. Developing management techniques to reduce turfgrass injury while maintaining herbicide efficacy is imperative for effective POST control of goosegrass within turfgrass stands. Immediately incorporating products via irrigation, or tank-mixing products such as chelated iron $(\mathrm{Fe})$, could reduce turf injury while maintaining control efficacy. The current study focused on turfgrass injury only. Kerr and McCarty (2017) noted little reduction in goosegrass control efficacy of topramezone and carfentrazone $+2,4-\mathrm{D}+$ dicamba + MCPP when irrigated immediately at the same rates used in the current study.

Topramezone (Pylex Herbicide 2.8C; BASF Corporation, Research Triangle Park, NC) and mesotrione (Tenacity 4L; Syngenta Professional Products, Greensboro, NC) are 4-hydroxyphenylpyruvate dioxygenase inhibitors absorbed through roots and shoots (Brosnan et al., 2014; Elmore et al., 2011a). Simazine (Princep 4L; Syngenta Professional Products, Greensboro, NC) and metribuzin (Sencor 75DF; Bayer Crop Science, Research Triangle Park, NC) are photosynthetic (PSII) inhibitors (Nimbal et al., 1996). Simazine is absorbed through the roots; metribuzin is absorbed mostly through the roots (Abusteit et al., 1985; Sheets, 1961). Carfentrazone-ethyl (shoot-absorbed) plus 2,4-D (root-absorbed) plus dicamba (root- and shoot-absorbed) plus mecoprop (mostly root-absorbed) (Speedzone 2.2L; PBI Gordon, KS City, MO) is effective for the control of many broadleaf weeds and goosegrass - the only grassy weed listed on the label (http://www.cdms. net/ldat/ld61R001.pdf) (Beck et al., 2014). The site of herbicide uptake is an important factor to consider when developing techniques to reduce turfgrass injury. If an herbicide is shoot-absorbed, immediate irrigation will most likely remove a certain amount of product, thus possibly reducing efficacy. If an herbicide is fully or partly root-absorbed, immediate irrigation could potentially reduce turfgrass injury while maintaining desirable weed control efficacy.

The objectives of the trials were 1) to evaluate turfgrass injury after the use of POST goosegrass control options and 2) to assess whether irrigating immediately after herbicide application reduces turfgrass injury on mature stands of 'Tifway 419' bermudagrass [Cynodon dactylon (L.) Pers. $\times$ Cynodon transvaalensis Burtt-Davy].

\section{Materials and Methods}

Two field sites were used in these experiments: the Walker Golf Course, Clemson University, Clemson, SC; and the Auburn Sports Surface Field Laboratory, Auburn University, Auburn, AL. In 2017, the Clemson University trial site received $25 \mathrm{~kg} \mathrm{~N} / \mathrm{ha}$ in May and $12.5 \mathrm{~kg} \mathrm{~N} / \mathrm{ha}$ in August. The site was mowed weekly at $25 \mathrm{~mm}$ with no other herbicides, fungicides, or plant growth regulators applied. In 2017, the Auburn University trial site received $25 \mathrm{~kg} \mathrm{~N} / \mathrm{ha}$ on $4 \mathrm{Apr}$., $20 \mathrm{~kg} \mathrm{~N} / \mathrm{ha}$ on $24 \mathrm{Apr}$., and $2.5 \mathrm{~kg} \mathrm{~N} / \mathrm{ha}$ and $0.59 \mathrm{~L} /$ ha trinexapac-ethyl (Primo Maxx, Syngenta Professional Products, Greensboro, NC) on 13 and 27 June, 11 and 25 July, 7 and 22 Aug. Fertilizer was applied at both trial sites using the nitrate source N20-4.4P16.6K (Harrell's Turf Specialty, Inc., Lakeland, FL). The trial area was mowed three times weekly at $13 \mathrm{~mm}$. No other herbicides or fungicides were applied during the 2017 
Table 1. Irrigation, herbicides, formulations, and rates used in two experiments: one in Clemson, SC, and one in Auburn, AL, 2017.

\begin{tabular}{|c|c|c|c|}
\hline Irrigation $^{z}$ & Trade name ${ }^{y}$ & Common name & Rate (kg a.i./ha) \\
\hline Yes & Untreated control & - & - \\
\hline Yes & Pylex 2.8C & Topramezone & 0.0123 \\
\hline Yes & Speedzone & Carfentrazone $+2,4-\mathrm{D}+$ dicamba $+\mathrm{MCPP}$ & 0.5 \\
\hline Yes & Speedzone $2.2 \mathrm{~L}+$ Pylex $2.8 \mathrm{C}$ & Carfentrazone $+2,4-\mathrm{D}+$ dicamba $+\mathrm{MCPP}+$ topramezone & $0.5+0.0123$ \\
\hline Yes & Sencor $75 \mathrm{DF}$ & Metribuzin & 0.42 \\
\hline Yes & Tenacity $4 \mathrm{~L}$ & Mesotrione & 0.28 \\
\hline Yes & Princep 4L & Simazine & 0.87 \\
\hline Yes & Tenacity + Princep 4L & Mesotrione + simazine & $0.28+0.87$ \\
\hline No & Untreated control & - & - \\
\hline No & Pylex 2.8C & Topramezone & 0.0123 \\
\hline No & Speedzone & Carfentrazone $+2,4-\mathrm{D}+$ dicamba $+\mathrm{MCPP}$ & 0.5 \\
\hline No & Speedzone $2.2 \mathrm{~L}+$ Pylex $2.8 \mathrm{C}$ & Carfentrazone $+2,4-\mathrm{D}+$ dicamba $+\mathrm{MCPP}+$ topramezone & $0.5+0.0123$ \\
\hline No & Sencor $75 \mathrm{DF}$ & Metribuzin & 0.42 \\
\hline No & Tenacity $4 \mathrm{~L}$ & Mesotrione & 0.28 \\
\hline No & Princep 4L & Simazine & 0.87 \\
\hline No & Tenacity + Princep 4L & Mesotrione + simazine & $0.28+0.87$ \\
\hline
\end{tabular}

${ }^{\mathrm{z}}$ Irrigation applied to a depth of $0.66 \mathrm{~cm}(0.25 \mathrm{inch})$ immediately after treatment.

${ }^{\mathrm{y}}$ All treatments were mixed with a nonionic surfactant (Induce ${ }^{\circledR}$; Helena Chemical, Collierville, TN) at $0.25 \% \mathrm{v} / \mathrm{v}$ in $2-\mathrm{L}$ bottles.

MCPP = 2-(2-methyl-4-chlorophenoxy) propionic acid.

Table 2. Visual turfgrass injury on a percentage basis in response to herbicide treatments (treatment effect) and immediate irrigation (irrigation effect) in Clemson, SC, and Auburn, AL, 2017.

\begin{tabular}{|c|c|c|c|c|c|}
\hline & \multirow[b]{2}{*}{$\mathrm{kg}$ a.i./ha } & \multicolumn{4}{|c|}{ Turfgrass injury $(\%)^{z}$} \\
\hline & & $4 \mathrm{DAT}$ & $1 \mathrm{WAT}$ & 2 WAT & $4 \mathrm{WAT}$ \\
\hline \multicolumn{6}{|l|}{ Treatment $^{\mathrm{y}}$} \\
\hline Control & - & $0 \mathrm{c}$ & $0 \mathrm{e}$ & $0 \mathrm{e}$ & $0 \mathrm{~b}$ \\
\hline Topramezone & 0.0123 & $9 \mathrm{~b}$ & $48 \mathrm{a}$ & $81 \mathrm{a}$ & $28 \mathrm{a}$ \\
\hline $\begin{array}{l}\text { Carfentrazone + 2,4-D + } \\
\text { dicamba + MCPP }\end{array}$ & 0.5 & $13 \mathrm{ab}$ & $13 \mathrm{~cd}$ & $13 \mathrm{~d}$ & $5 \mathrm{~b}$ \\
\hline $\begin{array}{l}\text { Carfentrazone }+2,4-\mathrm{D}+ \\
\text { dicamba }+\mathrm{MCPP}+\text { topramezone }\end{array}$ & $0.5+0.0123$ & $17 \mathrm{a}$ & $40 \mathrm{a}$ & $60 \mathrm{~b}$ & $19 \mathrm{a}$ \\
\hline Metribuzin & 0.42 & $18 \mathrm{a}$ & $21 \mathrm{bc}$ & 8 de & $6 \mathrm{~b}$ \\
\hline Mesotrione & 0.28 & $8 \mathrm{~b}$ & $16 \mathrm{~cd}$ & $11 \mathrm{~d}$ & $3 \mathrm{~b}$ \\
\hline Simazine & 0.87 & $8 \mathrm{~b}$ & $10 \mathrm{~d}$ & $12 \mathrm{~d}$ & $7 \mathrm{~b}$ \\
\hline Mesotrione + simazine & $0.28+0.87$ & $9 \mathrm{~b}$ & $25 \mathrm{~b}$ & $27 \mathrm{c}$ & $8 \mathrm{~b}$ \\
\hline$P$ value & & $<0.0001$ & $<0.0001$ & $<0.0001$ & $<0.0001$ \\
\hline \multicolumn{6}{|l|}{ Irrigation } \\
\hline Yes & & $6 \mathrm{~b}$ & $12 \mathrm{~b}$ & $17 \mathrm{~b}$ & $6 \mathrm{~b}$ \\
\hline No & & $14 \mathrm{a}$ & $31 \mathrm{a}$ & $35 \mathrm{a}$ & $12 \mathrm{a}$ \\
\hline$P$ value & & $<0.0001$ & $<0.0001$ & $<0.0001$ & $<0.0001$ \\
\hline
\end{tabular}

${ }^{\mathrm{z}}$ Means with the same letter within the same column are not statistically different based on Tukey's honestly significant difference test $(\alpha=0.005)$.

${ }^{\mathrm{y}}$ All treatments were mixed with a nonionic surfactant (Induce ${ }^{\circledR}$; Helena Chemical, Collierville, TN) at $0.25 \% \mathrm{v} / \mathrm{v}$ in $2-\mathrm{L}$ bottles.

DAT = days after treatment; WAT = weeks after treatment; MCPP = 2-(2-methyl-4-chlorophenoxy) propionic acid.

growing season. Except for specific irrigation timing treatments, both sites were irrigated normally to prevent moisture stress.

Four replications of $1-\mathrm{m} \times 1-\mathrm{m}$ plots were used in a randomized complete block design. Treatments were control ( \pm irrigation); topramezone (Pylex 2.8C, \pm irrigation); carfentrazone $+2,4-\mathrm{D}+$ dicamba + MCPP (Speedzone 2.2L, \pm irrigation); carfentrazone + 2,4-D + dicamba + MCPP in combination with topramezone ( \pm irrigation); metribuzin (Sencor $75 \mathrm{DF}, \pm$ irrigation); mesotrione (Tenacity $4 \mathrm{~L}, \pm$ irrigation); simazine (Princep $4 \mathrm{~L}, \pm$ irrigation); and mesotrione + simazine ( \pm irrigation) (Table 1). All treatments were mixed with a nonionic surfactant $\left(\right.$ Induce $^{\circledR}$; Helena Chemical, Collierville, TN) at $0.25 \% \mathrm{v} / \mathrm{v}$ in $2-\mathrm{L}$ bottles. Herbicides were applied 14 Aug. 2017 using a pressurized carbon dioxide backpack boom sprayer with a water carrier volume of $187 \mathrm{~L} /$ ha through 8003 flat-fan nozzles (Tee jet; Spraying Systems Co., Roswell, GA). Irrigated treatments were applied immediately with a hand hose pre-
Tukey's honestly significant difference test $(P=0.05)$.

\section{Results and Discussion}

Location was analyzed statistically and visually for effects. No significant effect was detected and the data were combined. Location was not part of the statistical model for data analysis of the visual turfgrass injury or NDVI ratings. The main irrigation effect for visual turfgrass injury across all herbicide treatments was significant $(P<0.0001)$ at 4 DAT, 1 WAT, 2 WAT, and 4 WAT (Table 2). At 4 DAT, nonirrigated plots experienced the greatest injury (14\%), followed by irrigated plots $(6 \%)$ (Table 2). At 1 WAT, nonirrigated plots experienced the greatest injury $(31 \%)$, followed by irrigated plots $(12 \%)$ (Table 2 ). At 2 WAT, nonirrigated plots experienced the greatest injury $(35 \%)$, followed by irrigated plots (17\%) (Table 2). At 4 WAT, nonirrigated plots experienced the greatest injury $(12 \%)$, followed by irrigated plots $(6 \%)$ (Table 2).

The main herbicide treatment effect for calibrated to apply $0.6 \mathrm{~cm}$ or 0.25 inch $(\approx 6.3 \mathrm{~L})$.

Plots were rated visually for turfgrass injury (scale of $0 \%$ to $100 \%$, with $100=$ dark-green, dense turfgrass; $0=$ dead, brown turfgrass; and $30=$ minimally acceptable turfgrass), and NDVI. The measurement of NDVI was calculated as

$$
\mathrm{NDVI}=\frac{\mathrm{R}_{935}-\mathrm{R}_{661}}{\mathrm{R}_{935}+\mathrm{R}_{661}},
$$

where $R_{935}$ is the reflectance of near-infrared radiation at $935 \mathrm{~nm}$ and $\mathrm{R}_{661}$ is the reflectance of visible red radiation at $661 \mathrm{~nm}$ (Bremer et al., 2011; Trenholm et al., 1999) (Greenseeker Handheld Crop Sensor; Trimble Navigation Limited, Westminster, CO). Plots were rated at $4 \mathrm{DAT}, 1 \mathrm{WAT}, 2 \mathrm{WAT}$, and $4 \mathrm{WAT}$.

Analysis of variance and means separation were performed on all data sets using the SAS statistical software package JMP Pro 13.2 (SAS Institute Inc., Cary NC). Data were analyzed individually for each evaluation date. Significant means were separated using irrigated and nonirrigated visual turfgrass injury was significant $(P<0.0001)$ at 4 DAT, 1 WAT, 2 WAT, and 4 WAT (Table 2). At 4 DAT, metribuzin and carfentrazone $+2,4-\mathrm{D}+$ dicamba + MCPP in combination with topramezone-treated plots experienced the greatest injury $(\approx 18 \%)$, followed by carfentrazone $+2,4-\mathrm{D}+$ dicamba + MCPP alone (13\%) (Table 2). At 1 WAT, topramezone-treated plots experienced the greatest injury $(48 \%)$, followed by carfentrazone $+2,4-\mathrm{D}+$ dicamba $+\mathrm{MCPP}$ in combination with topramezone $(40 \%)$, and mesotrione plus simazine (25\%) (Table 2$)$. At 2 WAT, topramezone-treated plots experienced the greatest injury ( $81 \%)$, followed by carfentrazone + 2,4-D + dicamba + MCPP in combination with topramezone $(60 \%)$ and mesotrione plus simazine (27\%) (Table 2$)$. At 4 WAT, topramezone-treated plots again experienced the greatest injury $(28 \%)$, followed by carfentrazone $+2,4-\mathrm{D}+$ dicamba + MCPP in combination with topramezone (19\%) (Table 2). 
Table 3. Visual turfgrass injury on a percentage basis in response to herbicide treatments (treatment effect) and immediate irrigation (irrigation effect) in Clemson, SC, and Auburn, AL, 2017.

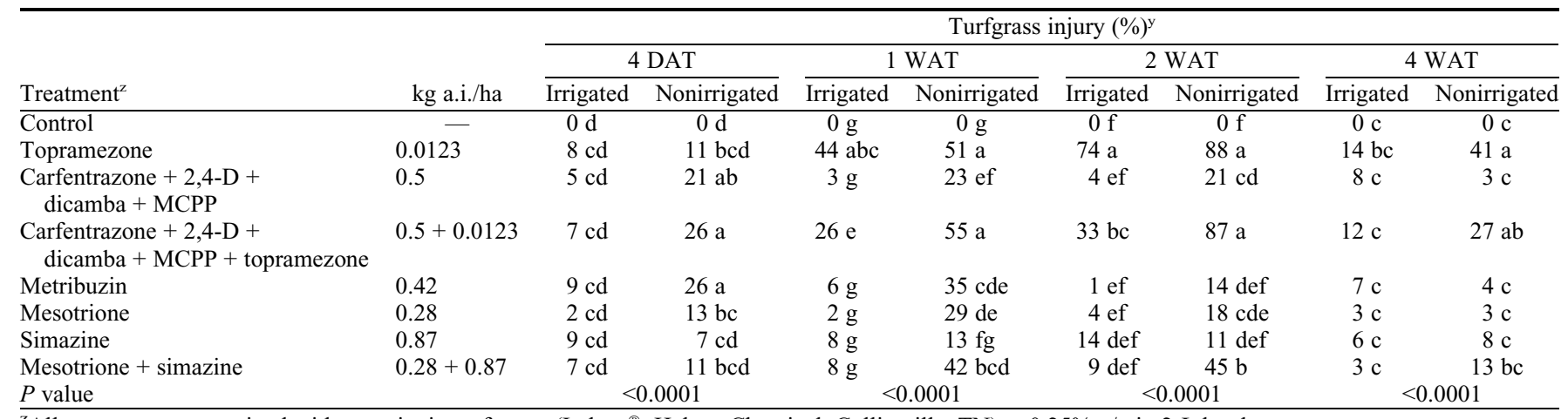

${ }^{\mathrm{z}}$ All treatments were mixed with a nonionic surfactant (Induce ${ }^{\circledR}$; Helena Chemical, Collierville, TN) at 0.25\% v/v in 2-L bottles.

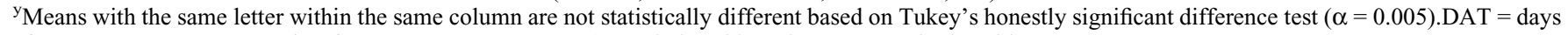
after treatment; WAT = weeks after treatment; MCPP = 2-(2-methyl-4-chlorophenoxy) propionic acid.

Table 4. Turfgrass injury ratings based on normalized differences vegetative indices (NDVI) in response to herbicide treatments (treatment effect) and immediate irrigation (irrigation effect) in Clemson, SC, and Auburn, AL, 2017.

\begin{tabular}{|c|c|c|c|c|c|}
\hline & \multirow[b]{2}{*}{ kg a.i./ha } & \multicolumn{4}{|c|}{ Turfgrass injury (NDVI) $)^{z}$} \\
\hline & & $4 \mathrm{DAT}$ & $1 \mathrm{WAT}$ & 2 WAT & 4 WAT \\
\hline \multicolumn{6}{|l|}{ Treatment $^{\mathrm{y}}$} \\
\hline Control & - & $0.781 \mathrm{a}$ & $0.681 \mathrm{ab}$ & $0.669 \mathrm{a}$ & $0.625 \mathrm{a}$ \\
\hline Topramezone & 0.0123 & $0.735 \mathrm{ab}$ & $0.606 a b c$ & $0.442 \mathrm{~d}$ & $0.546 \mathrm{~b}$ \\
\hline $\begin{array}{l}\text { Carfentrazone + 2,4-D + } \\
\text { dicamba }+ \text { MCPP }\end{array}$ & 0.5 & $0.735 \mathrm{ab}$ & $0.620 \mathrm{abc}$ & $0.604 \mathrm{ab}$ & $0.611 \mathrm{at}$ \\
\hline $\begin{array}{l}\text { Carfentrazone + 2,4-D + } \\
\text { dicamba + MCPP + topramezone }\end{array}$ & $0.5+0.0123$ & $0.716 \mathrm{~b}$ & $0.582 \mathrm{c}$ & $0.484 \mathrm{~cd}$ & $0.598 \mathrm{at}$ \\
\hline Metribuzin & 0.42 & $0.745 \mathrm{ab}$ & $0.576 \mathrm{c}$ & $0.590 \mathrm{abc}$ & $0.630 \mathrm{a}$ \\
\hline Mesotrione & 0.28 & $0.758 \mathrm{ab}$ & $0.614 a b c$ & $0.590 \mathrm{abc}$ & $0.624 \mathrm{a}$ \\
\hline Simazine & 0.87 & $0.774 \mathrm{a}$ & $0.690 \mathrm{a}$ & $0.662 \mathrm{a}$ & $0.625 \mathrm{a}$ \\
\hline Mesotrione + simazine & $0.28+0.87$ & $0.765 \mathrm{ab}$ & $0.602 \mathrm{bc}$ & $0.519 \mathrm{bcd}$ & $0.610 \mathrm{at}$ \\
\hline$P$ value & & 0.0108 & 0.0001 & $<0.0001$ & 0.0257 \\
\hline \multicolumn{6}{|l|}{ Irrigation } \\
\hline Yes & & $0.769 \mathrm{a}$ & $0.644 \mathrm{a}$ & $0.612 \mathrm{a}$ & $0.621 \mathrm{a}$ \\
\hline No & & $0.734 \mathrm{~b}$ & $0.599 \mathrm{~b}$ & $0.528 \mathrm{~b}$ & $0.596 \mathrm{~b}$ \\
\hline$P$ value & & 0.0003 & 0.0017 & $<0.0001$ & 0.0446 \\
\hline
\end{tabular}

${ }^{\mathrm{z}}$ Means with the same letter within the same column are not statistically different based on Tukey's honestly significant difference test $(\alpha=0.005)$.

${ }^{y}$ All treatments were mixed with a nonionic surfactant (Induce ${ }^{\circledR}$; Helena Chemical, Collierville, TN) at $0.25 \% \mathrm{v} / \mathrm{v}$ in $2-\mathrm{L}$ bottles.

$\mathrm{DAT}=$ days after treatment; WAT $=$ weeks after treatment; MCPP $=2-(2-$ methyl-4-chlorophenoxy $)$ propionic acid.

The treatment-by-irrigation interaction was also significant $(P<0.0001)$ at $4 \mathrm{DAT}$, 1 WAT, 2 WAT, and 4 WAT (Table 3). At 4 DAT, carfentrazone + 2,4-D + dicamba + MCPP in combination with topramezone and metribuzin alone nonirrigated experienced the greatest injury $(26 \%)$, followed by carfentrazone $+2,4-\mathrm{D}+$ dicamba + MCPP nonirrigated (21\%) (Table 3$)$. At 1 WAT, plots with the greatest injury were carfentrazone + 2,4-D + dicamba + MCPP in combination with topramezone nonirrigated $(55 \%)$ and topramezone alone nonirrigated $(51 \%)$; followed by topramezone alone irrigated (44\%), mesotrione plus simazine nonirrigated $(41 \%)$, metribuzin nonirrigated $(35 \%)$, and mesotrione nonirrigated (29\%) (Table 3). At 2 WAT, plots with the greatest $(\approx 88 \%)$ injury were topramezone nonirrigated and carfentrazone + 2,4-D + dicamba + MCPP in combination with topramezone nonirrigated, followed by topramezone irrigated (74\%), mesotrione plus simazine nonirrigated $(45 \%)$, and carfentrazone $+2,4-\mathrm{D}+$ dicamba + MCPP in combination with topramezone irrigated (33\%) (Table 3). At 4 WAT, plots with the greatest injury were topramezone nonirrigated (41\%) and carfentrazone $+2,4-\mathrm{D}+$ dicamba + MCPP in combination with topramezone nonirrigated (27\%) (Table 3).

The main herbicide treatment effect for irrigated and nonirrigated NDVI turfgrass injury ratings was significant at 4 DAT, 1 WAT, 2 WAT, and 4 WAT (Table 4). At 4 DAT, plots treated with carfentrazone + 2,4-D + dicamba + MCPP in combination with topramezone had the lowest (least-green) NDVI rating (0.716) (Table 4). At 1 WAT, the lowest NDVI ratings were for carfentrazone $+2,4-\mathrm{D}+$ dicamba + MCPP in combination with topramezone (0.582) and metribuzin (0.576). At 2 WAT, the lowest NDVI ratings were for topramezone alone (0.442); carfentrazone + 2,4-D + dicamba + MCPP in combination with topramezone (0.484); and mesotrione plus simazine (0.519). At 4 WAT, the lowest NDVI rating was for topramezone (0.546).

The main irrigation effect for NDVI turfgrass injury ratings was significant at 4
DAT, 1 WAT, 2 WAT, and 4 WAT (Table 4). At 4 DAT, nonirrigated plots experienced the lowest NDVI ratings $(0.734)$, followed by irrigated plots (0.769) (Table 4). At 1 WAT, nonirrigated plots had the lowest NDVI ratings (0.599), followed by irrigated plots (0.644) (Table 4). At 2 WAT, nonirrigated plots had the lowest NDVI ratings (0.582), followed by irrigated plots $(0.612)$ (Table 4$)$. At 4 WAT nonirrigated plots had the lowest NDVI ratings (0.596), followed by irrigated plots (0.621) (Table 4).

Overall, without irrigation, turfgrass injury from topramezone was greatest (up to 88\%) at 2 WAT, and from metribuzin $(\approx 29 \%)$ at 1 WAT. Of the two treatments, injury from metribuzin was least damaging throughout the study. Cox et al. (2017) noted similar turfgrass injury 2 WAT with topramezone. Elmore et al. (2011b) reported turfgrass injury from topramezone was greatest 2 WAT $(\approx 47 \%)$, although in our study the turfgrass injury was greater (up to $81 \%$ ). Simazine and mesotrione treatments alone maintained acceptable turfgrass injury $(\approx 13 \%)$; however, when applied in combination, considerable (up to $27 \%$ ) turfgrass injury occurred. Elmore et al. (2011b) noted acceptable mesotrione turfgrass injury throughout a 5-week study. Simazine alone provided acceptable turfgrass injury $(\leq 30 \%)$, consistent with previous research (Sharpe et al., 1989).

Turfgrass injury was reduced by irrigation for all herbicides used alone and in combination in these trials. Topramezone alone nonirrigated had the greatest turfgrass injury $(\approx 81 \%$ at 2 WAT) (Table 2$)$; however, combining topramezone with carfentrazone $+2,4-\mathrm{D}+$ dicamba $+\mathrm{MCPP}$ reduced turfgrass injury ( $\approx 60 \%$ at 2 WAT) (Table 2 ). When the combination was irrigated, turfgrass injury was reduced further $(\approx 33 \%$ at 2 WAT $)$ (Table 3).

In conclusion, immediate incorporation of POST herbicide treatments by irrigating with $0.66 \mathrm{~cm}$ reduces turfgrass injury to mostly acceptable levels.

\section{Literature Cited}

Abusteit, E.O., F.T. Corbin, D.P. Schmitt, J.W. Burton, A.D. Worsham, and L. Thompson. 
1985. Absorption, translocation, and metabolism of metribuzin in diploid and tetraploid soybean (Glycine max) plants and cell cultures. Weed Sci. 33:618-628.

Beck, L.L., A.J. Patton, and D.V. Weisenberger. 2014. Mowing before or after an herbicide application does not influence ground ivy (Glechoma hederacea) control. Appl. Turfgrass Sci. 12 Sept. 2018. <https://dl.sciencesocieties. org/publications/ats/abstracts/11/1/ATS-20130017-RS>

Bremer, D.J., H. Lee, K. Su, and S.J. Keeley. 2011. Relationships between normalized difference vegetation index and visual quality in coolseason turfgrass: II. Factors affecting NDVI and its component reflectance. Crop Sci. 51:2219-2227.

Brosnan, J., G. Breeden, A. Patton, and D.V. Weisenberger. 2014. Triclopyr reduces smooth crabgrass bleaching with topramezone without compromising efficacy. Appl. Turfgrass Sci. 12 Sept. 2018. <https://dl. sciencesocieties.org/publications/ats/pdfs/ 10/1/ATS-2013-0038-BR>.

Cox, M.C., S.S. Rana, J.R. Brewer, and S.D. Askew. 2017. Goosegrass and bermudagrass response to rates and tank mixtures of topramezone and triclopyr. Crop Sci. 57:310-321.

Elmore, M.T., J.T. Brosnan, D.A. Kopsell, and G.K. Breeden. 2011a. Methods of assessing bermudagrass responses to HPPD-inhibiting herbicides. Crop Sci. 51:2840-2845.

Elmore, M.T., J.T. Brosnan, D.A. Kopsell, G.K. Breeden, and T.C. Mueller. 2011b. Response of hybrid bermudagrass (Cynodon dactylon $\times C$. transvaalensis) to three HPPD-inhibitors. Weed Sci. 59:458-463.

Kerr, B. and L.B. McCarty. 2017. Tank mixtures and irrigation timing for goosegrass control. Proc. Southern Weed Sci. Soc. 70:221.

Lee, L.J. and J. Ngim. 2000. A first report of glyphosate-resistant goosegrass (Eleusine indica (L.) Gaertn) in Malaysia. Pest Mgt. Sci 56:336-339.
McCullough, P.E., J. Yu, P.L. Raymer, and Z. Chen. 2016. First report of ACCase-resistant goosegrass (Eleusine indica) in the United States. Weed Sci. 64:399-408.

Mudge, L.C., B.J. Gossett, and T.R. Murphy. 1984. Resistance of goosegrass (Eleusine indica) to dinitroaniline herbicides. Weed Sci. 32:591-594.

Nimbal, C.I., C.N. Yerkes, L.A. Weston, and S.C. Weller. 1996. Herbicidal activity and site of action of the natural product sorgoleone. Pestic. Biochem. Physiol. 54:73-83.

Sharpe, S.S., R. Dickens, and D.L. Turner. 1989. Herbicide effects on tensile strength and rooting of bermudagrass (Cynodon dactylon) sod. Weed Technol. 2:353-357.

Sheets, T.J. 1961. Uptake and distribution of simazine by oat and cotton seedlings. Weeds 9:1-13.

Trenholm, L.E., R.N. Carrow, and R.R. Duncan. 1999. Relationship of multispectral radiometry data to qualitative data in turfgrass research. Crop Sci. 39:763-769. 